\title{
IbM Penerapan Microsoft Office Excel untuk Menunjang Profesionalisme Guru dalam Pengelolaan Nilai Siswa di SD Syahidin Semarang
}

\author{
Novita Kurnia Ningrum ${ }^{1}$, Yani Parti Astuti ${ }^{2}$, Usman Sudibyo ${ }^{3}$ \\ Teknik Infromatika Fakultas Ilmu Komputer Universitas Dian Nuswantoro \\ e-mail: ${ }^{* 1}$ novita.kn@dsn.dinus.ac.id, ${ }^{2}$ yaniparti@dsn.dinus.ac.id, ${ }^{3}$ usmansudibyo@dsn.dinus.ac.id
}

\begin{abstract}
Abstrak
Evaluasi merupakan salah satu bagian terpenting dalam kegiatan belajar mengajar di sekolah khususnya sekolah dasar. Hasil evaluasi dijadikan sebagai tolok ukur tercapainya tujuan dari pembelajaran yang sudah berlangsung. Salah satu bentuk evaluasi adalah pemberian scorring atau penilaian pada siswa selama pembelajaran berlangsung. Penilaian yang sudah ada perlu diolah sesuai dengan kebutuhan data nilai dari guru yang bersangkutan. Selama ini guru di SD Syhidin mengolah data nilai siswa dengan menghitung manual. Beberapa kendala yang dialami oleh guru adalah belum mampu mengolah nilai secara komputerisasi sdangkan mengolah data nilai secara manual membutuhkan waktu lama dan hasilnya belum tentu akurat. Hal tersebut tidak sesuai dengan kondisi saat ini, karena guru diharapkan dapat memberikan informasi nilai dengan cepat. Oleh karena itu guru membutuhkan ketrampilan dalam hal pengolahan data secara otomatis dengan memanfaatkan teknologi yang ada. Microsoft Office Excel dapat digunakan sebagai media untuk mengelola data nilai siswa, baik menghitung secara aritmatika, memilah data dan diagram. Memalaui kegiatan IPTEK bagi masyarakat ini, diberikan materi berupa teori text dan praktikum. Para guru SD Syahidin mempraktikkan langsung menggunakan Microsoft Office Excel. Adapun materi praktikum meliputi menghitung aritmatika, memilah data, menyajikan nilai dalam tabel dan diagram. Dengan adanya kegiatan IPTEK bagi masyarakat ini, diharapkan guru di SD Syahidin mampu mengolah data nilai secara terkomputerisasi dan menghasilkan informasi nilai yang lebih akurat.
\end{abstract}

Kata Kunci-pengolahan data siswa, microsoft office excel, SD Syahidin 


\section{PENDAHULUAN}

SD Islam Syahidah terletak di Kelurahan Krobokan Kecamatan Semarang Tengah, Kota Semarang. Kelas yang disediakan di SD Islam Syahdiah mulai dari tingkat kelas 1 SD hingga kelas 6 SD. Sesuai dengan Peraturan Menteri Pendidikan dan Kebudayaan (Permendikbud) No. 23 tahun 2016 tentang Standar Penilaian Pendidikan bahwa Kurikulum yang digunakan untuk Sekolah setingkat SD adalah Kurikulum 2013 (K 13). Berdasarkan Permendikbud No .23 tahun 2016 tersebut mengatur mengenai standar penilaian pendidikan, yang menjelaskan bahwa penilaian adalah proses pengumpulan dan pengolahan informasi untuk mengukur pencapaian hasil belajar peserta didik. Untuk itu diperlukan kemampuan yang cukup dalam mengoperasikan komputer, khususnya SD Islam Syahidah sehingga dapat mengumpulkan dan mengolah nilai Siswa secara optimal.

Saat ini Kementrian pendidikan dan Kebudayaan sudah menyediakan aplikasi Dapodik untuk menyeragamkan standar penilaian siswa secara nasional. Dengan adanya Aplikasi Dapodik tersebut, para Guru diwajibkan untuk menginputkan hasil penilaian terhadap Siswa. Dengan demikian, kemampuan untuk mengoperasikan komputer merupakan kebutuhan mutlak bagi para Guru. Dalam rangka menunjang kinerja Guru dalam mengajar, Guru juga ditutut untuk bias menyajikan materi yang maenarik dan interaktif untuk para siswanya. Dengan demikian diharapkan siswa dapat memperoleh pengetahuan yang cukup dan nilai sesuai dengan standar komptensi minimum yang dibutuhkan. Selain itu Guru juga membutuhkan kemampuan menggunkan komputer khususnya untuk keperluan perkantoran dan mengelola file kerja. Hal tersebut dibutuhkan untuk mengelola berkas administratif untuk kebutuhan penunjang profesi.

Untuk saat ini perangkat komputer yang dimiliki oleh SD Islam Syahidah sudah sesuai kebutuhan. Akan tetapi Guru dan Staf administrasi yang memiliki ketrampilan menggunakan komputer masih terbatas. Kondisi SD Islam Syahidah tersebut menunjukkan bahwa masih membutuhkan pengetahuan dan praktikum untuk meningkatkan kemampuan Guru menggunakan komputer.

Berdasarkan pemaparan di atas, maka pada pengabdian masyarakat dengan skema Ipteks bagi Masyarakat ini kami akan memberikan materi berupa teori dan praktik pada Guru SD Islam Syahidah. Materi tersebut meliputi Microsof Office Power Point, Microsoft Office Word dan Microsoft Office Excel. Melalui kegiatan ini diharapkan Guru di SD Islam Syahidah dapat mengoperasikan komputer khususnya menggunakan Aplikasi Microsoft Office sehingga dapat membantu meningkatkan kinerja guru dalam Kegiatan Belajar Mengajar.

\section{METODE PENELITIAN}

Pengabdian masayarakat program Ipteks bagi Masyarakat (IbM) ini dilaksanakan dengan metode praktikum. Tempat yang digunakan adalah Ruang Kelas di SD Islam Syahidah Kelurahan Krobokan Kota Semarang.

Rencana kegiatan akan dilaksanankan selama 3 hari. Adapun alur dari metode yang digunakan sebagai berikut:

1. Persiapan

1.1. Menyiapkan hardware sesuai spesifikasi yang dibutuhkan.

1.2. Menyipakan software berupa paket mMicrosoft office.

2. Pelaksanaan

2.1. Penyampaian materi Modul 1, bab mengolah data siswa dengan Microsoft Office Excel.

2.2. Penyampaian materi Modul 2, bab menghitung aritmatika dengan Microsoft Office Excel.

2.3. Penyampaian materi Modul 3, bab imengatur tampilan atau layout dengan Microsoft Office Excel. 


\section{HASIL DAN PEMBAHASAN}

Hasil dari pengbdian masyarakat skema IbM ini berupa modul yang diberikan dalam bentuk hardcopy maupun soft copy kepada guru SD Islam Syahidin.

Luaran yang dicapai adalah mengupload hasil pengabdian masyarakat skema IbM di SD Islam pada channel youtube Abdimasku. Dan bisa di akses di link youtube:

https://www.youtube.com/watch?v=Xt1HUmvaBLk. Dan akan submit ke jurnal ABDIMASKU LPPM Universitas Dian Nuswantoro.

\section{KESIMPULAN DAN SARAN}

Berdasarkan kegiatan yang sudah kami laksanakan, dapat disimpulkan bahwa kebutuhan akan ketrampilan mengoperasikan komputer di kalangan guru khususnya guru di SD Islam Syahidin cukup tinggi. Akan tetapi tidak seimbang dengan kemampuan para guru dalam mengoperasikannya. Hal tersebut disebabkan karena fasilitas baik dalam bentuk hardware maupun layanan di SD Islam Syahidin yang tidak memadai untuk menunjang ketrampilan para guru mengoperasikan komputer.

Tim pengabdian masyarakat kami merupakan tim pertaman melaksanakan kegiatan menunjang ketrampilan mengoperasikan komputer di SD Islam Syahidin. Oleh karena itu, agar materi berkesinambungan ada baiknya jika materi pengabdian masyarakat dengan skema yang sama adalah microsoft office word.

\section{DAFTAR PUSTAKA}

Bohlman , H., \& Dundas, M. (2002). The Legal, Ethical and International Environment of Business. (5th ed). . Cincinnati, OH: West.

Kuncoro, M. ( 2002). Metode Kuantitatif Teori dan Aplikasi Untuk Bisnis dan Ekonomi. Yogyakarta: UPP AMP YKPN.

Laudon, Kenneth C.; Laudon, Jane P.;. (2012). Management Information System. Pearson.

Newmark, P. ( 1991). About translation. Clevedon [England]: Multilingual Matters.

England.

Wahono, R. S. (2008). Memanfaatkan Internet untuk Personal Branding . Retrieved from Ilmu Komputer.org. 